\title{
The Past is With Us and Yet to Come: A Hauntological Analysis of Tsutomu Mizushima's Anime Series, 'Another'
}
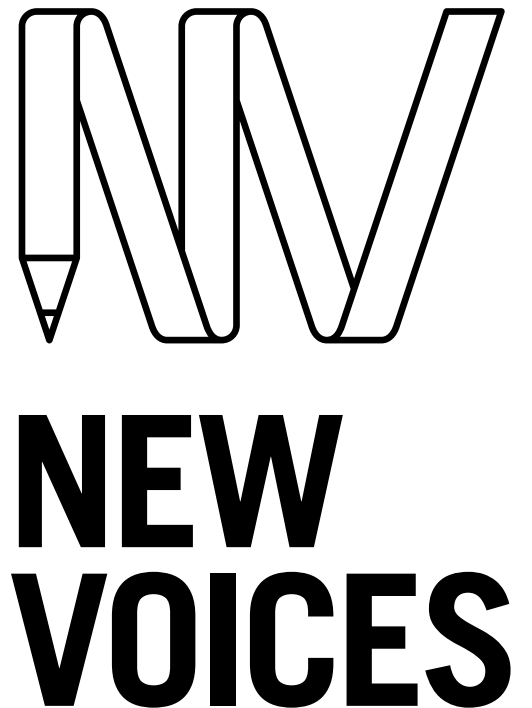

IN JAPANESE

\section{LUKE BEATTIE} STUDIES

The University of Notre Dame Australia

(D) https://orcid.org/0000-0002-8637-4278

\begin{abstract}
Japanese director Tsutomu Mizushima's 2012 animated television series, Another, presents a narrative whereby one social group's refusal to accept an unexpected death triggers an intergenerational curse. This paper takes a close reading of Mizushima's anime, showing how its narrative contends that the present-and by default the future-is not self-sufficient but instead relies upon understandings of the past. The analysis uses the lens of Jacques Derrida's theory of hauntology, which opens up a space for discursive accounts of the presence of the past in the present and its influence on the future, and therefore serves as a powerful tool for interrogating questions of war memory. I demonstrate that Another exemplifies the use of anime as a critical medium, showing how it uses allegory to explore the motivations and consequences of Japan's lack of a dominant historical narrative about the war and the resulting intergenerational effects of this historical consciousness problem. As Japan continues to debate remilitarisation and the fate of Article 9 in its constitution, it seems particularly apt to revisit Mizushima's Another, which illustrates the dangers of ignoring the spectre of history.
\end{abstract}

\section{KEYWORDS}

3.11; anime; atomic victimhood; Derrida; hauntology; history; narrative; post-war; World War II
JaPANFOUNDATION \&

BRINGING JAPAN TO YOU

To link to this article:

https://doi.org/10.21159/nvjs.12.04

ISSN 2205-3166

New Voices in Japanese Studies is an interdisciplinary, peer-reviewed journal showcasing the work of emerging scholars with ties to Australia or New Zealand and research interests in Japan.

All articles can be downloaded free at newvoices.org.au

(c) The Japan Foundation, Sydney and Luke Beattie, 2020.

\section{(c)}

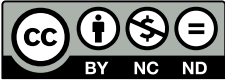

This work is licensed under a Creative Commons Attribution-NonCommercialNoDerivatives 4.0 International License. 


\section{INTRODUCTION}

Japanese director Tsutomu Mizushima [水島 努]'s 2012 animated television series Another [アナザー] exemplifies the use of anime to convey a critical vision of society. In this paper, I draw on this approach to Japanese anime to read Another as a critique of Japan's nuclear experience during World War II and its resulting historical consciousness problem. Jacques Derrida's theory of hauntology, outlined in Specters of Marx [1993], theorises the dangers of ignoring the past. By viewing Another through this lens, it will be shown that Another presents a strong allegory for the effects of the ideological violence that is wrought by cultures when conflicting memories of a troubled past vie for legitimacy within social and political arenas.

Another is a twelve-episode ghost story about an intergenerational curse resulting from the censorship of a historical traumatic event. It is based on the 2009 novel of the same name by Yukito Ayatsuji [綾辻 行人] and the subsequent manga version by Hiro Kiyohara [清原 紘; 2010-2012]. Another first aired from January to March 2012 on Kitanihon Broadcasting, TVQ Kyushu Broadcasting and several other independent Japanese TV stations before receiving an international DVD and Blu-ray release on July 30, 2013. In 2020, it ranked as the thirty-seventh most popular anime of all time on the English-language fan site, My Anime List. ${ }^{1}$ Despite its 2012 release and enduring popularity, Another has yet to be identified in scholarship as an example of anime as a vehicle for social critique. As the debate to revise Article 9 of the Japanese Constitution continues, with its threat to alter the pacifist constitution that has anchored national life since 1947, it seems particularly timely to explore the problems of historical consciousness that dominate the thematic concerns of Mizushima's anime. ${ }^{2}$

\section{WAR MEMORY IN JAPAN}

Japan does not have a dominant wartime narrative but rather a multiplicity of conflicting narratives that have been formed for political gain or to circumvent responsibilities. Akiko Hashimoto (2015) observes that, despite two-thirds of the Japanese population having been born after World War II, Japan is far from arriving at a national consensus regarding its involvement and defeat in the war, and its war memory is prey to many volatile, unresolved issues. Japan's official treatment of war guilt and the commemoration of war criminals (the 'Yasukuni problem') continue to attract both international

1 See https://myanimelist.net/topanime.php?type=bypopularity.

2. Article 9 of the Japanese Constitution was written by the Occupation authorities at the time of Japan's World

War II surrender in 1947, and states: "Aspiring sincerely to an international peace based on justice and order, the Japanese people forever renounce war as a sovereign right of the nation and the threat or use of force as means of settling international disputes. In order to accomplish [this] aim...land, sea, and air forces, as well as other war potential, will never be maintained. The right of belligerency of the state will not be recognised" (see https:// japan.kantei.go.jp/constitution_and_government_of_japan/constitution_e.html).

Japanese Prime Minister Shinzō Abe's tenure as LDP leader ends in September 2021. As recently as December 2019, Abe has stated on public record that he is "determined not to back down from my cause of revising Article 9" (Abiru 2019). The revision of Article 9 is a contentious issue in Japan, with the U.S.-drafted Constitution and its prohibition of Japanese aggressive militarisation "seen by Japan's conservatives as a humiliating symbol of defeat", while others see it as protection against "entanglement in foreign conflicts" (Sieg 2019). 
and domestic criticism. ${ }^{3}$ Japan also faces ongoing claims for compensation and apology related to wartime forced labour, institutionalised prostitution ('comfort women') and its treatment of prisoners of war. Michael Lucken (2017) writes, "the dominant characteristic of Japanese historiography on World War II is fragmentation, an absence of unity" (182), and further posits that post-war Japanese governments have presented the nation's involvement in World War II as "a transgression on behalf of military leaders" (182), leaving questions of blame and responsibility vague. In a similar vein, Hashimoto concludes that these conflicting memories of Japan's troubled past continue to fuel national controversies $(2015,1-24)$.

Conflicting attitudes within Japan's political landscape drive its historical consciousness problem. A plurality of views exists within the Japanese government regarding its official World War II narrative. At the time of writing in 2020, the ruling Liberal Democratic Party under Prime Minister Shinzō Abe continues to adopt an approach that downplays Japan's aggressive role in World War II and its war crimes (Lucken 2017, 197-98). In opposition to the conservative nationalist parties such as the LDP, Japan's leftist parties, such as the Japanese Communist Party and the Social Democratic Party, advocate that Japan should make reparation for war crimes committed against China and Southeast Asia (197-98). These conflicting divisions, along with competing victim groups within Japan as well as the various international victims of Japan's wartime expansionist agenda, show that historical memory, while seeking truth, can only achieve an approximation of said truth. Ultimately, this is because "history is a science based on selection" (Lucken 2017, 173). What is included and omitted from history is based on the maintenance of a narrative unity that aligns with the moral and political agendas of the ruling parties.

This agentless historical automatism is best illustrated by Japan's memorial practices regarding the bombings of Hiroshima and Nagasaki. The ruined dome of Hiroshima's Commercial Exhibition Hall, with its clock stopped at $8.15 \mathrm{am}$, is one such example. Other memorial practices see bells and gongs rung at the precise time the atomic bombs were dropped, and memorial museums at both Nagasaki and Hiroshima offer limited space to the historical context around the Allied bombings, instead featuring reconstructions of the events complete with sound effects. This severance of the atomic bombs from a World War II context is understandable in light of the acquittal of rulers before the Tokyo Tribunal. It is notable, says Dower (1999), that "no heads of the...'Kempeitai' (the military police) were indicted..., [nor were any] industrialists who had profited from aggression and had been ultimately involved in paving the 'road to war"' $(464-65) .{ }^{4}$ Dower also points out the exoneration of the Japanese Emperor as another example of the post-war

\footnotetext{
3 The 'Yasukuni problem' refers to the Yasukuni Shinto shrine and accompanying historical museum that "situates the Asian theatre of World War II in the framework of a '100-year war' of Japan against the West, with the noble objective of liberating other Asian peoples from European and American colonialism," omitting the effects of Japanese colonial rule and war crimes (Saaler 2014, 147). Internationally, visits to the shrine are seen as a violation of the separation between politics and religion enshrined in the Japanese constitution (Saaler 2014). 4 The Kempeitai was the Japanese Army's military police. Its primary responsibility was to root out and destroy any dissenting individuals or groups resisting Japanese occupation. The Kempeitai was also in charge of the Japanese military court with the authority to execute those suspected of not following the ideology of Imperial Japan. The Kempeitai is known to have been responsible for unlawful means of interrogation, including physical torture, and hundreds if not thousands of executions, and is also thought to have been responsible for some of the worst atrocities committed during World War II. See Lamont-Brown (1998).
} 
separation of the state from responsibility for acts committed during the war. ${ }^{5}$ More recently, critics have noted that new memorials unveiled in Hiroshima and Nagasaki in the early 2000s fail to contextualise the bombings, focusing instead on mourning. ${ }^{6}$

This representation of the historical events of Hiroshima and Nagasaki as being instantaneous with no lead-up, and most importantly, as agentless, was reproduced following the 2011 Tohoku earthquake and tsunami, with its resulting explosions of several nuclear reactors at the Fukushima Daiichi Nuclear Power Plant. It is notable that the minute's silence for the Tohoku Disaster is held at the time of the earthquake and not at the time of the explosion of the first nuclear reactor it caused, an incident with transgenerational consequences (Lucken 2017, 229-34). This again shows a concept of history as a series of either unique void-like events, as in the case of Hiroshima and Nagasaki, or a natural occurrence, as in the case of the Fukushima disaster. This attitude of a historical automatism is further shown by the political and media coverage that surrounded the Fukushima disaster. From March 2011 to March 2012, public figures drew parallels between the devastation caused by the Allied bombings and the Tohoku tsunami, which reactivated the horror and ideological rift within Japanese society regarding wartime and nuclear threat (Lucken 2017, 270).

The danger of an attitude of historical progress that frames its metanarrative around an agentless automatism is that it tacitly articulates an ideology that "erases the condition of the defeated or the oppressed" (Brown 2001, 158). Nowhere is this danger more present than in the official treatment of survivors of the atomic bombings of Hiroshima and Nagasaki, termed Hibakusha (被爆者). The Japanese government criteria to attain official Hibakusha status involves complicated documentation that requires either a certified statement by a public official; a photograph proving the applicant's specific location at the time of the bombing; written certification from two different people, excluding blood relatives to the third degree, testifying to the applicant's location at the time of the bombing; or a corroborative story from a fellow survivor acknowledging that they and the applicant sheltered together (Southard 2017, 300). As can be imagined, such documentation is not easily attainable. What is most poignant about the status of Hibakusha is the vast quantity of people that do not attempt an application. This is due to the way that "Hibakusha-even those with economic and social status and with no visible injuries or illness-were routinely rejected as marriage partners because of widespread fears about radiation-related illnesses and possible genetic effects on children" (Southard 2017, 204). This fear has extended to second-generation Hibakusha who are currently seeking damages for social ostracism and a life of fear regarding their health. This prejudice based on fear clearly paints Hibakusha as 'Other': spectral beings whom official discourses would rather ignore.

\footnotetext{
5 The US administration decided not to bring Emperor Hirohito to trial at the Tokyo indictments, as it determined that allowing the Emperor to retain his position would be advantageous in helping the Japanese people come to terms with their defeat. See Dower (1999).

6 In regard to the lack of contextualisation surrounding the Hiroshima and Nagasaki war memorials,

Lisa Yoneyama $(1999,3)$ states: "Whether within mainstream national historiography, which remembers Hiroshima's (and Nagasaki's) atomic bombing as victimization experienced by the Japanese collectivity, or in the equally pervasive, more universalistic narrative on the bombing(s) that records it as having been an unprecedented event in the history of humanity, Hiroshima (and Nagasaki) memories have been predicated on the grave obfuscation of the prewar Japanese Empire, its colonial practices, and their consequences".
} 
This fear of the 'Other' and the painting of Hibakusha as 'Other' is cemented in the wording of the Hibakusha Relief Law (被爆者救済法). This Act contains overtones that make it clear that the payments of medical fees provided by the Act are not state redress. Specifically, the Act reinforces that the recipients of payments are not receiving them as victims of World War II trauma, a category which would have the potential to implicate the Japanese government given its own active participation in World War II. Instead, the legislation indicates that any monetary redress received through the Hibakusha Relief Law is to be viewed as charitable social security payment for those immediately affected by the atomic bombs, and not as compensation for events that were in any way related to Japan's wartime actions (Takeuchi 2018). They are, ultimately, a bandaging - an "isolating and concealing" - of "the wounds of the past in a manner directly antithetical to their healing" (Blake 2008, 2-3). This example represents a failure to take responsibility for the past, and in doing so elevate Hibakusha from the classification of 'Other' to a human whose history is that of Japan's as a whole. The refusal to compensate Hibakusha as victims of World War II-and by extension, of Japan's own involvement in the war-can be seen as an evasion of responsibility for the past, effectively censoring Hibakusha and trapping them within a thick present that curtails their future. It is with this censoring of history in order to maintain the present that the concept of hauntology assumes its full ethical potential.

\section{DERRIDA'S HAUNTOLOGY AND HISTORICAL CONSCIOUSNESS}

Japan's contested wartime narrative is one example of the problem of historical consciousness which Jacques Derrida interrogates through his theory of hauntology, as presented in Specters of Marx [1993]. In line with a "strong tradition" of interpretation and usage of 'haunting narratives', hauntology envisions history's relationship to the present as a form of 'haunting', "especially when that history is shameful, traumatic and repressed" (Leeder 2009, 71). It figures history as a 'spectre'; a timeless other that exists in the present yet is not represented in the discourse of the day. To commune with the spectre of history, therefore, is to commune with an absent 'Other.' The future similarly features in the hauntology paradigm: Derrida notes that the historical 'Other,' the revenant, "that which comes back" $(2006,11)$, can also be arrivant, "that which remains to come" (28), as hauntology acknowledges the lost future potential inherent in every past.

Derrida writes that recognising the spectre of history is an act of present political responsibility. Coining the term 'spectropolitics', Derrida positions the essential ontologies "of present as actual reality and objectivity (as dependent on) dissipating the phantom", thereby making the ghost of the past part of the dialogues of today (Derrida 2006, 232). Derrida strengthens his argument by pointing out that the insubstantial or virtual, when unaddressed, can become a larger and more powerful force than an ontology of thinking or being. Further, he contends that by viewing the spectre as being of mere historiographical interest to the present, we are creating an attitude of historical progress that frames its metanarrative around an emergent future that treats the past and present as givens. Hauntology 
mourns this disappearance of "a whole mode of social imagination or the capacity to conceive of a world radically different from the one in which (we) currently live" (Fisher 2012, 16). ${ }^{7}$ As an antidote to this phenomenon, Derrida advocates a use of historical memory to undo the inevitability or given-ness of the present through a continual questioning and de-censoring of the past, which in turn opens channels of communication with the spectre in the interests of the future.

Tsutomu Mizushima's Another incorporates both the revenant spectre, in the form of a ghost, and the arrivant spectre, in the form of lost futures. Derrida's hauntology offers us a productive model for understanding the interconnected nature of these forces. Although the application of hauntology in a philosophical engagement with anime is unprecedented, some scholars have applied Derridean discourse to anime in order to extend and reinforce political and philosophical theories that have real-world implications. For example, Jane Goodall's "Hybridity and the End of Innocence" (2007) reads Hideki Takayama's 1987-1989 anime series Legends of the Overfiend through Derrida's theory of différance. For Derrida:

Nothing is ever one (singular), but always at least two (dual). As for any trace, mark, or inscription to be what it is it has to be an opposition to what it is not. Therefore if it is repetition that makes it possible to think sameness or identity, it does so only in so far as it introduces proliferating difference.

(Hill 2007, 16-17)

Using this Derridean discourse that sees repetition and otherness as inseparable, Goodall addresses the overt duality of Legend of the Overfiend's principal character, Amano Jyaku, a hybrid man/beast. Goodall's interpretation of Derrida's différance via the dualism at the core of the series' protagonist is truly enlightening and as such bears repeating:

Dualism is the enemy of difference...It is not structural but dynamic. It is not about signifiers but about forces. Whether its chosen principles are good and evil, innocence and experience, feminine and masculine, reason and energy, or any other of the great metaphysical oppositions, dualism remains volatile and is always dramatic because it is always antagonistic. Each of the two sides devours subdivisions (differences) in an all-consuming drive to confront its other head on.

(Goodall 2007, 169)

Goodall's use of Derridean theory is complemented by Pauline Moore's "When Velvet Gloves Meet Iron Fists: Cuteness in Japanese Animation" (2007), which discusses anime's use of a 'cute' aesthetic in relation to its youthful protagonists and zoomorphic characters, through a Derridean deconstruction of the word 'cute'. Moore's tracing of the etymology of the word 'cute' to its first English-language appearance in 1731 as a shortened form of 'acute' (complete with an opening apostrophe), and defined as "clever, shrewd, cunning", paints anime's 'cute' aesthetic as a form of hyper-innocence $(2007,120)$. The defeated often appear in their weakness as irrelevant and trifling. Moore argues that these 'cute' figures of anime can be positioned 
as a reaction to the lingering shadow of Japan's World War II defeat and the subsequent American occupation of Japan. In other words, they are the inherited benign face that Japan turns towards the West. Yet, as Moore points out, these 'cute' benign figures are placed within "technological landscapes of death, destruction and danger" and when "they fight back", they become 'acute', malign beings (Moore 2007, 130-31). Moore's 'cute/acute' beings and Goodall's man/beast characters, when read through the lens of Derrida against the context of Japan's involvement in World War II, can be seen as dualistic - not only in their personal hybridity, but as bridging the opposition of past and future. Their duality simulates the repressed 'Other' that confronts the West head on. Ultimately, these dual figures suggest that the present is often reliant on having disavowed the ghosts of an unresolved past. This distinctly hauntological idea can be read at the core of Mizushima's Another, which sees the return of disruptive ghosts that history has sought to excise.

\section{ANOTHER}

The main narrative of Another revolves around a curse triggered in 1972 by the refusal of high school Class 3-3 to accept the death of a classmate named Misaki Yomiyama. Following his death, Misaki Yomiyama becomes a mythic figure for Class 3-3. The class leaves his desk unoccupied, not in the spirit of memorialisation, but rather of denial. The students of Class 3-3 act as though Misaki is still amongst them and refuse to speak of his death. This denial of an event in history enables the manifestation of an actual spectral presence that becomes the starting point for the narrative society of Another. Set in the fictional provincial Japanese town of Yomiyama, the series opens in 1999 and follows a fourteen-year-old boy named Koichi Sakakibara, who has relocated from Tokyo. Arriving at his new school and joining Class 3-3, Koichi is shaken by the strange behaviour of his fellow classmates, particularly their apparent unwillingness to acknowledge the existence of Mei Misaki, a girl with an eyepatch who sits, ignored, at the back of the class. As the series unfolds, Koichi, with difficulty, discovers that Class 3-3 is cursed. In refusing to accept and acknowledge Misaki Yomiyama's death in 1972, Yomiyama's classmates triggered a curse that began with his spectral return. From that time, each successive Class 3-3 has been plagued by further unexpected deaths of those connected to the class. With each death, a new 'Another' returns to inhabit Class 3-3-a former student or faculty member who appears to be alive but is actually dead-in unacknowledged physical form. After the curse has run its annual course, the circumstances surrounding the deaths occasioned by the curse are subject to mass amnesia, in line with the original Class 3-3's denial of Yomiyama's death.

Over the years, recognition of this phenomena has seen Class 3-3 implement methods to limit the deaths caused by the curse. Class 3-3 adopts a 'one equals one' society, theorising that the assignment of a class member to the role of pseudo-ghost (the role Mei Misaki occupies when Koichi arrives) would allow room for the real spectre to join the class, thereby strengthening Class 3-3's official historical narrative, which refuses to acknowledge Yomiyama's mo

.

.


death. ${ }^{8}$ This method of accommodating the curse was thought to be a way of preventing the spate of deaths caused each year by the historical ghosts. In the year that Koichi Sakakibara enters Class 3-3, student Izumi Akazawa has been appointed head of 'countermeasures', a student group formed to police the maintenance of the curse. Izumi is vigilant in adopting the mathematical formula of 'one equals one', ensuring that Class 3-3 has the correct number of students in order to prevent any outliers. Meanwhile, the character of Mei Misaki has been chosen by Class 3-3 to become the pseudo-ghost, to allow room for the historical spectre to become human should it appear.

Although excluded from the official life of Class 3-3, Mei is free to come and go as she pleases within the society of the Class, as her pseudo-ghost status-reinforced by her occupation of the desk formerly belonging to the deceased Misaki Yomiyama-sees it imperative that peers and teachers alike ignore her. However, an inadvertent violation of this imperative triggers a resurgence of the curse. Arriving in Yomiyama with no knowledge of the curse, Koichi begins a friendship with Mei, which dislodges her pseudoghost status but importantly also allows Mei and Koichi to investigate the truth that lies behind the curse.

\section{SHOCKS AND SOCIUS: THE HAUNTOLOGICAL IN ANOTHER}

The above synopsis of Another's plot reflects the primary tenet of Derrida's theory of hauntology: that the repression of historical events leads to the repetition of social and political impulses that confine society to the maintenance of an established ideological system, due to failure to dissipate the spectre of past trauma. The irony is that in order to dispense with the spectre, one must initially call it into being. It is the failure of Class 3-3 of 1972 to accept the death of Misaki Yomiyama-to call his ghost into being, so to speak-that sees subsequent classes trapped within a sociopolitical system that is "reduced to the administration of an already established system" (Fisher 2012, 16). It is no accident that throughout Another, Misaki Yomiyama is portrayed as having been both intellectually and physically gifted, virtuous and popular, and coming from Tokyo-the aspirational representative of Japan as a whole. In short, for his classmates, Misaki Yomiyama exemplified an ideal. If, as Arthur Bradley argues, a sovereign gains their sovereignty through not being of the same order as those over whom they preside (2013, 795), then it is not too much of a leap to position Yomiyama as the sovereign of his class, a point reinforced by the fact that he shares his name with the town in which Another is set. In light of this, the refusal of Class 3-3 to accept Misaki Yomiyama's death, and therefore the death of the sovereign ideal, becomes understandable.

Ultimately, the world of Another is concerned with maintaining the denial of a threatening event, as opposed to addressing the said event in order to 
enable historical progress. This narrative premise of Another encapsulates Derrida's theory of hauntology and its underlying argument that the denial of past tragedy sees society-in this case, Class 3-3-stuck within a repeating temporal loop, "a cultural time (that) has folded back in on itself" (Fisher $2014,9)$. It also figures Derrida's hauntological vision of the society that has lost its future, in the sense that the class cannot imagine a society different from its own. Similarly, as noted earlier in this paper, Japan can also be seen as stuck in its own repeating temporal loop, as shown by the political and media coverage of the 2011 Tohoku earthquake and tsunami, which drew parallels with the nuclear attacks on Hiroshima and Nagasaki. It is not too much to say that the nuclear disaster of 2011 became, in public and political discourse, the return of the spectre of Hiroshima and Nagasaki. Likewise, the denial of Misaki Yomiyama's death in Another returns in the manifestation of additional ghosts, either in the spectral form of the actual deceased or as the symbolic spectre of those living members of Class 3-3 who are cast in the role of pseudo-ghost in attempts to counteract the curse.

According to the lore of the curse, the persistent inclusion of Misaki Yomiyama as a present, living member of the class following his death sparked a spate of further deaths. These deaths occurred sporadically and were confined to members of Class 3-3 and their immediate families. This curse can be seen to represent the implications of the repression of historical trauma. The denial of Misaki Yomiyama's death effectively leaves him trapped within the present, the trauma of his untimely death in the past denied. Derrida's spectres, though, are both revenant (past) and arrivant (future). That is, within every past there is also a latent future, the imaginative potential of which Misaki Yomiyama is denied. Thus, the concept of "transgenerational trauma", which encompasses the transmission of both familial and societal trauma across generations (Atkinson 2017, 4), plays out in the subtext of Another. It is the subsequent deaths caused by the denial of the death of Yomiyama that turn the transgenerational implications of unresolved trauma into literal lost futures. Writing on war memory, Ruth Kluger, who experienced the World War II Holocaust as a child, states: "Where there is no grave, one cannot mourn properly; one remains forever tied to a loss that never becomes real" (2003, 80). Gabriele Schwab (2010) expands on Kluger's idea, writing that "Violent histories generate psychic deformations passed on from generation to generation" (48). Japan's lack of a dominant wartime narrative is not dissimilar to the absent grave that Kluger speaks of. Within the fictional narrative of Another, the "loss that never becomes real" looms large in the form of the spectre of Yomiyama, which successive generations of Class 3-3 cannot shake, and which shapes their every move. Another represents an analogy of the effects of transgenerational trauma that are brought about by a society's inability to mourn the unacknowledged, reflecting Japan's struggles with wartime memory.

There is a limit inherent in language with regard to reality: times when traditional models of cognition, and even representation itself, appear insufficient for bearing witness to horrific events. The atomic bombing of Japan was one such occurrence and its horror resides not only in the immense damage caused and its subsequent immeasurability, but also in the wrongs 
wrought upon its victims, both dead and alive, and in the impossibility of their testifying adequately in relation to such an unprecedented event (Lyotard 1988). ${ }^{9}$ Often, when faced with the cognitive limits of shocking events or experiences, there is a "self-defeating tendency to respectfully silence testimonies of trauma deemed so horrific as to be unspeakable" (Blake 2008, 4). This silencing results in a culture of secrecy around trauma, which for Class 3-3 physically manifests itself as the spectres that haunt their world. This sees the members of Class 3-3, whether they like it or not, become the ghost's coconspirators in their blind submission to the silence surrounding its origins. Further, this conspiracy of silence about the past under which Class 3-3 labours results in 'the disappearance of a whole mode of social imagination', a phenomenon that Derrida warns against with hauntology. In short, the students of Class 3-3, in their eagerness to conceal the past, cannot conceive of a future that is radically different from the one they inhabit.

That cultural trauma binds its victims in a conspiracy of concealment, an abstraction of history, goes a long way towards explaining why we cannot easily expose and hence exorcise the spectres of our past. Class 3-3's role as co-conspirators with the spectre sees the possibility of their making a stand against this power take on the form of social treason. Rather than unearth the identity of their ghost, the students of Class 3-3 incorporate it as a living member into their society. If, as noted earlier, history is indeed "a science based on selection" (Lucken 2017, 173), then this is epitomised by the transgenerational actions of Class 3-3, which can in turn be read as an allegory for Japan's differing narratives or omissions with regard to World War II. That is, for every narrative inclusion in order to support a particular historical ideological standpoint, it is necessary to exclude any differing viewpoint of events. For example, the curse looming over Class 3-3 is periodically triggered by the presence in their midst of a ghost: to be precise, a soul, and a body of memories, that refuses to lie quiet. This presence, which is connected to any of the many who have previously died due to the curse sparked by the denial of Yomiyama's death, constitutes an intolerable surface, an excess of meaning that cannot be accommodated within the group's totalising and coherent self-conception. That Mei Misaki shares her name with Misaki Yomiyama, the original ghost of the world of Another, is a clear signpost that individual identity incorporates and is thereby prey to the collective trauma of the past. It is Koichi's unexpected arrival in the class, and his ignorance of Mei's spectral status, that awakens the curse. But crucially, it is Izumi's lamentation that her mathematical formula had failed despite its initial appearance of correctness that forms a clear parallel to Alain Badiou's theory that any multiplicity applied to the 'one equals one' attitude threatens the dominant ideology, and as such must be excluded (2007).

\section{THE POLITICS OF EXCLUSION: THE REVOLUTIONARY POTENTIAL OF HAUNTOLOGY IN ANOTHER}

If the preservation of a dominant ideology relies on both present and historical censorship, then the censored elements have a revolutionary potential. This potential is mirrored in Mei's role as Class 3-3's sacrificial ghost, which sees

9 For discussion of the impossibility of adequate testimony related to traumatic events, see Lyotard 1988. 
her occupy a state of exclusion. It is only through the protocols of the society of Class 3-3 that Mei has the freedom to, with the aid of Koichi, investigate the truth that lies behind the curse. Mei's exclusion from the official narrative (through the necessity to ignore her) prevents her from being managed in a way that might allow the class to foresee or circumvent a public display of dissidence. After all, as in the unchanging society of Class 3-3, the dominant historical discourse of a society is, whether consciously or unconsciously, used primarily as a tool for social control in order to maintain existing power structures. When comparisons began to be made in Japan between the Allied atomic bombings of 1945 and the devastation of the Fukushima Daiichi Nuclear Power Plant caused by the 2011 Tohoku tsunami, part of the government discourse included comparing the Fukushima firefighters with World War II kamikaze pilots, a narrative that replaced fears of contamination with tropes of nationalistic heroism (Lucken 2017, 271). However, this attempt at allaying fears in regards to the use of nuclear power didn't stop anti-nuclear activists from mobilising tens of thousands of people to protest against Japan's nuclear power goals outside the Prime Minister's official residence in 2012 (Brown 2018). ${ }^{10}$ It is this subversive influence that Derrida references in the title of his hauntological text, Specters of Marx:

The 'specter of communism' that Marx and Engels wrote of in the first lines of The Communist Manifesto was just this kind of ghost: a virtuality whose threatened coming was already playing a part in undermining the present state of things.

(Fisher 2014, 22).

In short, if "history is controlled by structures of power that work to exclude and repress", then in turn "that repression creates subversive power hovering just below the surface", beyond official control (Leeder 2009, 72). The same is true in Another: Mei's exclusion from the society of Class 3-3, combined with class members' inability to acknowledge her existence, means that the class is unable to manage her subversive potential. This proves disastrous when Class 3-3's protocols are unexpectedly disrupted by an outsider, as Koichi's arrival at school sees him acknowledge Mei, a situation that the other members of Class 3-3 cannot prevent. How do you tell someone to ignore a ghost that does not exist?

As in Another, ignoring the spectre is difficult, and the present is not as independent from the past as it may appear. Whether it be the parallels drawn in Japan between the 2011 Fukushima disaster and the atomic bombings of 1945, or Koichi's innocent acknowledgment of Mei, the present reveals how the imagined linear relationship between past and future is reliant upon the censorship of that which prevents coherent management by the dominant power. With Koichi's acknowledgment of Mei, the curse of Class 3-3 sparks the return of sporadic deaths of individuals connected to the class. Mei, and by association Koichi, are free to discover the omitted narratives related to Class 3-3 due to the subversive potential inherent in their own spectral status. Mei and Koichi begin their research into the omitted narratives of Class 3-3 by tracking down past students. This leads them to discover a year when the curse appeared to have been triggered but suddenly ceased. Contacting 
a student from that year, Katsumi Matsunaga, Mei and Koichi are led to an ageing cassette tape hidden in their classroom storage cupboard. The contents of the cassette reveal to Mei and Koichi that the unexpected cessation of the curse was due to the accidental death of the 'Another', the spectre who had assumed physical form amongst the class. The fact that Mizushima articulates this memory device in the form of a superseded medium or media 'spectre' shows that, for the characters of Another, time has run out to ignore the past.

Attending the annual school trip to the Yomiyama Shrine, Mei and Koichi, along with their intimates, Naoya and Yuya, listen to the cassette and discover that on the same school trip fifteen years previously, Katsumi had accidently killed a fellow classmate. The lack of repercussions for this murder, and indeed, the failure of anyone to remember the slain student, allow Katsumi to realise that he had killed the true 'Another', and in doing so had stopped the curse. Mei and Koichi now realise that the present Class 3-3's survival is predicated on finding the historical spectre amongst them in order to send the "dead back to death" (Mizushima 2017). Unfortunately for Mei and Koichi, another member of the class, Takako, discovers the cassette and broadcasts its contents to the entire class, adding that she is convinced that Mei is not only their elected ghost, but also a real historical spectre. The final scenes of Another see the class descend into madness, first attempting to kill Mei and then turning on each other in an attempt to rid themselves of the 'Another'. Here, we see a 'survival of the fittest' scenario play out as the students fight against each other for their lives. Mizushima's directorial choice to persist with showing graphically violent attacks-and in several cases deaths-can be seen as an allegory for Japanese war memory.

\section{CONCLUSION: HAUNTOLOGY AS ETHICS}

The curse of Class 3-3 arises from historical censorship and presents a compelling analogy for post-war Japan's historical consciousness problem. The intergenerational legacy of the curse can be seen as a dramatisation of how, in a broader sense, memories of collective trauma remain within cultures and societies long after the events themselves. In contemporary Japan, the comparisons between the 1945 allied atomic bombings and the 2011 Fukushima Daiichi Nuclear Power Plant disaster show how memories of collective trauma not only endure but can even intensify with the passage of time. Hauntology, via the figure of the ghost, seeks to heal these temporal wounds-both historical and ideological-by theorising the spectres of the past in the present. This temporal in-betweenness, at the same time, opens up a space for all those historically marginalised as 'Other'. In Another, Mei Misaki is relegated to a physical embodiment of temporal in-betweenness as a function of her symbolic society's evasion of responsibility to all but the present. The exclusion of Mei into the void between the past and the present is analogous to the position of the Hibakusha in Japanese society. With limited official acknowledgement of their past, Hibakusha occupy a precarious space between past and present that also denies recognition for their lost futures.

\section{mo}

(1)


In its core refusal to silence the voices of the past and the marginalised voices of the present-all that is accorded the label of 'Other'-hauntology pledges a promise of responsibility to everyone, whether living or non-living, included or excluded, in pursuit of a more just, emancipatory, or felicitous future order. The promise of conversing with our ghosts or 'Others' through an incessant questioning of the socio-politically constructed nature of historical narratives becomes crucial when matters of historical importance are debated in the public sphere, such as the revision of Article 9 in Japan's constitution. In the end, the characters of Another fail to address the question of what kinds of memories are being excluded in specific contexts, or most importantly, what kinds of counter-memories may be forged to resist dominant practices and arrangements of power. These questions not only need to be interrogated in Japan, but should be of critical interest to us all.

Tsutomu Mizushima's Another provides a strong analogy for the difficulties that arise from Japan's historical consciousness problem, in relation to its competing World War II narratives. In doing so, it highlights, in a broader sense, that trauma remains with cultures and societies long after the events themselves. These enduring concerns, arising between the living and the dead, haunt on. In persistently counting their dead classmate Misaki Yomiyama among the living, Class 3-3 renders him neither past nor future but solely present. Through an application of Jacques Derrida's theory of hauntology we see that this denial of the past by Class 3-3 limits its members' future to the maintenance of the present: they cannot 'move on,' so to speak. Further, in refusing to acknowledge its history, Class 3-3 not only accords its historical ghosts the status of 'Other', but also sacrifices members of its current society to the role of 'Other' when their presence threatens the current ideology. Another provides a critical lesson in the dangers of not conversing with the ghosts of our past-a lesson that aligns with Derrida's hauntology. Though neither Mizushima nor Derrida provide a final response as to how we are to effectively converse with our ghosts, it seems that they both see the future deriving from the incessant questioning of historical narrativesa questioning not only applicable to Japan as it debates remilitarisation within a landscape of unresolved past wartime narratives, but one relevant to all societies.

\section{REFERENCES}

Abiru, R. 2019. "Shinzo Abe Determined to have Japan's Constitution Revised Before his Term Ends." Japan Forward, 7 December. Accessed 2 March, 2020. https://japan-forward.com/shinzo-abe-determined-to-have-japansconstitution-revised-before-his-term-ends/.

Atkinson, M. 2017. The Poetics of Transgenerational Trauma. New York and London: Bloomsbury Academic.

Badiou, A. 2007. Being and Event. Translated by O. Feltham. London: Continuum. 
Blake, L. 2008. The Wounds of Nations: Horror Cinema, Historical Trauma and National Identity. Manchester and New York: Manchester University Press. https://doi.org/10.7228/manchester/9780719075933.001.0001.

Bradley, A. 2013. "Untimely Ripp'd: On Natality, Sovereignty and Unbearable Life.” English Studies 94 (7): 788-98. https://doi.org/10.1080/0013838X.2013. 840123.

Brown, A. 2018. Anti-Nuclear Protest in Post-Fukushima Tokyo. Abingdon, Oxon and New York: Routledge. https://doi.org/10.4324/9781315121611.

Brown, W. 2001. Politics Out of History. Princeton and Oxford: Princeton University Press.

Derrida, J. 2006. Specters of Marx. Translated by P. Kamuf. New York and London: Routledge Classics.

Dower, J. W. 1999. Embracing Defeat: Japan in the Wake of World War II. New York: W. W. Norton and Company.

Fisher, M. 2012. "What is Hauntology?" Film Quarterly 66 (1): 16-24. https://doi. $\operatorname{org} / 10.1525 /$ fq.2012.66.1.16.

Fisher, M. 2014. Ghosts of My Life: Writings on Depression, Hauntology and Lost Futures. London: Zero Books.

Goodall, J. 2007. "Hybridity and the End of Innocence." In The Illusion of Life II, edited by A. Cholodenko, 152-71. Sydney: Power Publications.

Hashimoto, A. 2015. The Long Defeat: Cultural Trauma, Memory, and Identity in Japan. Oxford and New York: Oxford University Press. https://doi. org/10.1093/acprof:oso/9780190239152.001.0001.

Hill, L. 2007. The Cambridge Introduction to Jacques Derrida. Cambridge: Cambridge University Press.

Kluger, R. 2003. Still Alive: A Holocaust Girlhood Remembered. New York: The Feminist Press, City University of New York.

Kyodo. 2017. “Children of Hiroshima Survivors Sue for Coverage under Hibakusha Assistance Law.” The Japan Times, 17 February. Accessed 9 October, 2019. https://www.japantimes.co.jp/news/2017/02/17/national/crime-legal/ children-hiroshima-survivors-sue-coverage-hibakusha-assistance-law/.

Lamont-Brown, R. 1998. Kempeitai: Japan's Dreaded Military Police. Stroud, Gloucestershire: Sutton Publishing Ltd.

Leeder, M. 2009. "Skeletons Sail an Etheric Ocean: Approaching the Ghost in John Carpenter's 'The Fog." Journal of Popular Film and Television 37 (2): 70-79. https://doi.org/10.3200/JPFT.37.2.70-79.

Lucken, M. 2017. The Japanese and the War: Expectation, Perception and the Shaping of Memory. New York: Columbia University Press. https:/doi.org/10.7312/ luck17702.

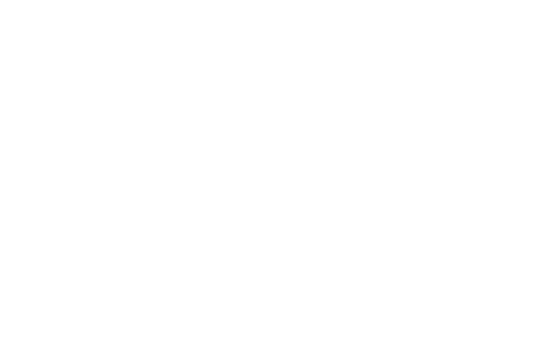

(1)


Lyotard, J. 1988. The Differend: Phrases in Dispute. Translated by G. Van Den Abbeele. Minneapolis: University of Minnesota Press.

Mizushima, T. (dir.). 2017. Another. Television series. Hanabee Entertainment.

Moore, P. 2007. "When Velvet Gloves Meet Iron Fists: Cuteness in Japanese Animation." In The Illusion of Life II, edited by A. Cholodenko, 119-51. Sydney: Power Publications.

Pradyumna, P. P. and U. Suganuma, eds. 2016. Japan After 3/11. Lexington, Kentucky: University Press of Kentucky.

Saaler, S. 2014. "Bad War or Good War? History and Politics in Post-War Japan." In Critical Issues in Contemporary Japan, edited by J. Kingston, 137-50. New York: Routledge.

Schwab, G. 2010. Haunting Legacies: Violent Histories and Transgenerational Trauma. New York: Columbia University Press.

Sieg, L. 2019. "Mission Unaccomplished-Abe's Drive to Revise Pacifist Constitution." The Japan Times, 19 November. Accessed 2 March, 2020. https://www. japantimes.co.jp/news/2019/11/19/national/politics-diplomacy/shinzo-aberevise-constitution/.

Southard, S. 2017. Nagasaki: Life After Nuclear War. UK: Souvenir Press Ltd.

Takeuchi, A. 2018. "Hibakusha: 78-yr-old Bringing War Victims Together to Protect Article 9, Receive Gov't Aid." The Mainichi, 18 May. Accessed 9 October, 2019. http://mainichi.jp/english/articles/20180518/p2a/00m/0na/019000c.

Yoneyama, L. 1999. Hiroshima Traces: Time, Space, and the Dialectics of Memory. Berkeley: University of California Press. https://doi.org/10.1525/ california/9780520085862.001.0001. 